\author{
EISSN:2706-7920 ISSN: 2077-4435 \\ DOI: $10.36632 / \mathrm{csi} / 2021.10 .1 .3$ \\ Journal homepage: www.curresweb.com \\ Pages: 18-28
}

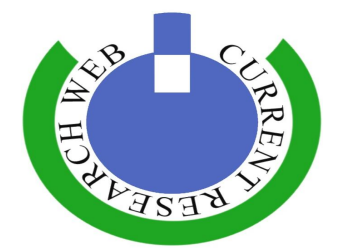

\title{
Using of Certain Biotic and Abiotic Inducers on Controlling Peanut Cercospora Leaf Spot
}

\author{
Mahmoud E.Y., Zeinab N. Hussien, Ibrahim M.M. and Heba Yousef
}

Plant Pathology Res. Ins., Agric. Res. Center, Giza., Egypt

\author{
Received: 05 December 2020 Accepted: 10 January $2021 \quad$ Published: 20 January 2021
}

\begin{abstract}
Cercospora leaf spot (CLS), early leaf spot (caused by Cercospora arachidicola) and late leaf spot (caused by Cercosporidium personatum) are the most important foliar diseases affecting peanut (Arachis hypogaea L.) throughout the world. Although, fungicide applications considered one of the important management strategies for controlling of CLS however, it causes hazards to human and animal health and increase environmental pollution, which makes the urgent need to find fungicides alternatives. In try to take this approach, the effectiveness of biotic inducers (Pseudomonas fluorescens and Bacillus subtilis) and abiotic inducers (chitosan at $1,2 \& 3 \mathrm{mM}$ and bion at 2,4 \& $8 \mathrm{mM}$ ), were tested in field trials on incidence of CLS compared to commercial fungicide as a check treatment. All tested inducers significantly reduced diseases severity of CLS compared to non-treated control in the two successive seasons 2018 and 2019. Generally, chitosan at $3 \mathrm{mM}$ and followed by chitosan at $2 \mathrm{mM}$ and $P$. fluorescens gave the highest effect on reducing of CLS. While, bion at $2 \mathrm{mM}$ gave the highest value of disease severity compared with control treatment in the two successive seasons. Increasing the concentration of chemical inducers (Abiotic treatments) caused increase in their reducing efficiency of diseases severity. This study indicated that, there is a correlation between induced resistance and some biochemical changes in peanut leaf tissues. Among these biochemical changes, the increase of phenol contents (free, conjugate \& total phenols) and oxidative enzyme activity (peroxidase, polyphenoloxidase and catalase) as well as total free amino acids and percentage of crude protein. The obtained data clearly showed the ability of some inducers treatments to achieve efficacy close to the efficiency of commercial fungicide in reducing CLS in peanuts, which may encourage the use of these inducers as an alternative to fungicides.
\end{abstract}

Keywords: Peanut, Cercospora leaf spot, chitosan, bion, Pseudomonas fluorescens, Bacillus subtilis and biochemical changes, fungicides.

\section{Introduction}

Groundnut (Arachis hypogaea L.) is one of the world's most important oilseed crops (Dwivedi et al., 2003), cultivated in more than 100 countries (FAO, 2011) and considered one of an important cash crop, as well as an important food source (Izge et al., 2007). In Egypt producing area 142642 fed. and a production of 198763 ton as mentioned by the yearly book 2019 of Economics and Statistics of the Economic Affairs Sectors, Agriculture Ministry in Egypt, however, it is susceptible to many diseases including leaf spots. Early leaf spot caused by Cercospora arachidicola $\mathrm{S}$. Hori (telemorph $=$ Mycosphaerella arachidis Deighton) and Late leaf spot caused by Cercosporidium personatum (Berk.\&M.A.Curtis) Deighton (telemorph $=$ Mycosphaerella berkeleyi Jenk) are the most important foliar diseases and major yield reducing factor of groundnut worldwide with an annual yield losses of 15 to $50 \%$ (Lijun et al., 1999 and Maninderpal, 2011).

Corresponding Author: Mahmoud E.Y., Plant Pathology Res. Ins., Agric. Res. Center, Giza., Egypt 
One of the important management strategies for Cercospora leaf spot epidemics rely on reducing the rate of disease spread by fungicide applications (Woodward et al., 2010). Indiscriminate application of fungicides for Cercospora leaf spot control may result in undesirable effects, e.g. development of fungicide-tolerant strains of leaf spot pathogens (Littrell, 1974) and increased severity of other diseases (Shokes and Culbreath, 1997). Moreover Fungicidal applications cause hazards to human health and increase environmental pollution (Garcia, 1993). Therefore, alternatives, eco-friendly approaches for control of plant diseases are needed such as induced resistance (Mandal et al., 2009).

Induced disease resistance can be defined as the process of active resistance dependent on the host plants physical or chemical barriers activated by biotic or abiotic agents, (Meena et al., 2001 and Walters et al., 2007). Induced resistance is characterized by many advantages such as; non-specific, systemic, has durable effect, safe for human and environment, and has a positive effect on plant growth and yield (Kuc, 1982). Some compounds e.g., chitosan and bezo $(1,2,3)$ thiodiazole-7-carbothioic-methyle ester (Bion), have been shown to induce resistance in plants (Mahmoud et al., 2006, Liu et al., 2007, Hussien 2011, Mahmoud et al., 2014, Chakraborty et al., 2020 and De Vega et al., 2021). Induction of systemic resistance sensitizes the plant to respond rapid after infection. These responses include phytoalexin accumulation, phenols, lignifications and activation of many enzymes such as peroxidase, polyphenoloxidase, catalase and chitinase (Meena, et al., 2001, Mahmoud et al., 2006, Hussien, 2011, Abdel Aal et al., 2012 and Mahmoud et al., 2014). In addition, many investigators reported that inducers of systemic resistance accumulated or enhanced new proteins in systemically protected leaves (Tuzun and Kloepper 1994). Treated peanut plants with induction compounds led to changes in the activity of phenylalnine ammonialyase, chitinase, beta-1.3- gluconase, peroxidase, polyphenoloxidase and in the contents of phenolic compounds (Meena et al., 2001, Mahmoud et al., 2006, Hussin 2011 and Mahmoud et al., 2014).

Bacillus and Pseudomonas are considering the important genera of Plant growthpromoting rhizobacteria (PGPR) (Karunanithi et al., 2000, Meena et al., 2001 and Mahmoud et al., 2016). Nonpathogenic rhizobacteria can induce a systemic resistance in plants that is phenotypically similar to pathogen-induced systemic acquired resistance (SAR). Rhizobacteriamediated induced systemic resistance (ISR) has been demonstrated against fungi, bacteria, and viruses in Arabidopsis, bean, carnation, cucumber, radish, tobacco, chili, tomato and grapevine (Van et al., 1998, Verhagen et al., 2010, Gruau et al., 2015 and Jayapala et al., 2019). Bacterial strains differ in their ability to induce resistance in different plant species, and plants show variation in the expression of ISR upon induction by specific bacterial strains. Bacterial determinants of ISR include lipopolysaccharides, siderophores, salicylic acid (SA) and pathogenesis related (PR) proteins. Whereas some of the rhizobacteria induce resistance through the SA-dependent SAR pathway, others do not and require jasmonic acid and ethylene perception by the plant for ISR to develop (Van et al., 1998 and Altinok et al., 2013).

The present studies have been conducted to investigate the effectiveness of such environmentally safe treatments i.e. biotic and abiotic inducers for control of peanut Cercospora leaf spot (CLS) as alternative fungicide.

\section{Materials and Methods}

\subsection{Source of biotic inducers:}

Tow known isolates of Pseudomonas fluorescens and Bacillus subtilis were obtained from culture collection of department of Onion, Garlic and Oil Plant Diseases, Plant Pathol. Res. Inst., Agric. Res. Center (ARC), Giza, Egypt and were identified by using Biolog technique (Carbon and amino acid utilization profile of microorganisms) Biolog TM microplates (Biolog, Inc., 3938 Trust way, Hayward, CA94545, USA) at the Unit of Identification of Microorganisms Plant Pathol. Res. Inst., Agric. Res. Center (ARC), Giza, Egypt (Mahmoud et al., 2016).

\subsection{Preparation of bacterial inoculum}

Bacterial suspensions $\left(1 \times 10^{6} \mathrm{cfu} / \mathrm{ml}\right)$ were prepared by dilution plate assay as described by Mahmoud et al., (2016). 


\subsection{Foliar treatments:}

The effectiveness of two abiotic inducers, e.g. Bion at 2, 4 and $8 \mathrm{mM}$ and chitosan at 1,2 and $3 \mathrm{mM}$, beside two biotic inducers e.g. P. fluorescens; and B. subtilis were tested to inhibition of diseases severity of Cercospora leaf spot (CLS). Each treatment was used as a foliar spray after 20 and 40 days from sowing. While fungicide Score EC $25 \%$ (Difenoconazole) was applied after 40 days from sowing at the rate of $50 \mathrm{ml} / 100$ liter (three times with interval 15 days).

\subsection{Disease assessment:}

a) Disease severity (early and late leaf spots combined) was assessed on a scale of $1-9$ as described by Subrahmanyam et al., (1995) where per cent infected leaf area was: $1=0 \%, 2=$ $1-5 \%, 3=6-10 \%, 4=11-20 \%, 5=21-30 \%, 6=31-40 \%$ and $7=41-60 \%, 8=61-80 \%, 9=$ $81-100 \%$. It was based on 20 tagged plants randomly selected from the middle rows of each plot. Obtained data were computed using the formula:

$$
\text { D.S. }=\frac{\Sigma \mathrm{n}}{\mathrm{N} \times 9} \times 100
$$

Where:

$$
\begin{aligned}
& \text { DS = Cercospora leaf spot severity (\%), } \\
& \Sigma \mathrm{n}=\text { Sum of individual ratings. } \\
& \mathrm{N}=\text { Total number of plants assessed. } \\
& 9=\text { Highest score on the severity scale. }
\end{aligned}
$$

b) Percentages of treatment efficacy in reducing the disease infection were calculated as follows:

$$
\begin{gathered}
\% \text { Treatment efficiency }=\frac{\text { Control-Treatment }}{\text { Control }} \times 100 \\
\% \text { Inducer efficiency to fungicide efficacy }=\frac{\text { Inducer efficiency }}{\text { Fungicides efficiency }} \times 100
\end{gathered}
$$

\subsection{Experiments implementation:}

Field experiments were carried out during 2018 and 2019 seasons in naturally infested field with CLS causal pathogens at Ismailia Experimental Station of Agriculture Research Center (ARC). The soil type was sandy loam (77\% sand, 11\% silt, 12\% clay; $\mathrm{pH} 7.98$ and EC 7.2). Peanut seeds, cv Giza 6, were used for sowing throughout this study. Seeds were sown on the first week of May with $10 \mathrm{~cm}$ spacing between plants. The experimental unit area was 10.5 $\mathrm{m}^{2}$ (1/400 fed.). The experiment was arranged in a completely randomized block design with three replicates. Cultural practices such as fertilization, irrigation were carried out as usual. Plants in individual plots were dug and inverted based on optimum maturity index. Pods were threshed, air-dried for three days then weighed.

\subsection{Biochemical changes associated with induced resistance:}

Samples of leaves were taken after two days from second foliar spraying and extracted according to Goldschmidt et al. (1968), then activities of the oxidative enzymes i.e., peroxidase (PO); polyphenoloxidase (PPO) and catalase (CAT) were determined according to Allam and Hollis (1972); Matta and Dimond (1963) and Maxwell and Bateman (1967), respectively and assayed using a spectrophotometer at 425, 495 and $240 \mathrm{~nm}$. respectively. The reaction substrate of each oxidative enzyme was pyrogallol, catechol and $\mathrm{H}_{2} \mathrm{O}_{2}$ for determining activity of peroxidase; polyphenoloxidase and catalase, respectively. Another samples were extracted in soxhlet units using $75 \%$ ethanol for 10-12 hrs then used to determine phenolic compounds; total 
free amino acids and percentage of crude protein as described by Snell and Snell, (1953), Moore and Stein (1954) and A.O.A.C. (1998) respectively. The Phenols and total free amino acids contents were also calculated as milligrams equivalent of catechol and argenin /g fresh weight of peanut leaves respectively.

\subsection{Statistical analysis:}

The data were statistically analyzed by analysis of variance (ANOVA) using the Statistical Analysis software "COStat 6.4" (CoStat, 2005). Means were separated by the Duncan test at $\mathrm{P} \leq 0.05$.

\section{Results}

\subsection{Effect of inducers treatments on CLS compared to Score fungicide under field conditions during two seasons 2018 and 2019:}

Data in Table (1) indicate that, all treatments (biotic or abiotic) showed significantly reduced the disease severity of peanut CLS compared to non-treated control in the two successive seasons 2018 and 2019.

In abiotic inducers, chitosan at all concentrates was higher than bion concentrates in reducing disease severity of CLS while, $P$. fluorescens was higher than B. subtilis in biotic inducers. On the other side fungicide treatment recoded the lowest value of CLS disease severity in the two successive seasons (Table 1).

Data in (Table 1) showed that, chitosan at $3 \mathrm{mM}$ and $2 \mathrm{mM}$ followed by P. fluorescens gave the highest efficiency in reducing disease severity of CLS compared to other inducer treatments, while bion at $2 \mathrm{mM}$ gave the lowest efficiency compared to other inducer treatments in the two successive seasons.

Data also showed that, there is a positive relationship between chemical inducers concentrations and their effect on the disease severity of CLS. Data clearly indicated that, increasing the concentration of chemical inducers led to increase their effect in reducing the disease severity in the two successive season 2018 and 2019 (Table 1).

Table 1: Effect of foliar spraying with inducers treatments on CLS compared to Score fungicide under field conditions during two successive seasons 2018 and 2019.

\begin{tabular}{|c|c|c|c|c|c|}
\hline \multirow{3}{*}{ Treatments } & \multirow{3}{*}{ Conc. } & \multicolumn{4}{|c|}{ Disease severity (DS\%) and Efficacy \% } \\
\hline & & \multicolumn{2}{|c|}{ Season 2018} & \multicolumn{2}{|c|}{ Season 2019} \\
\hline & & DS \% & Efficacy\% & DS \% & Efficacy\% \\
\hline & $2 \mathrm{mM}$ & $40.42 \mathrm{~b}$ & 30.77 & $36.07 \mathrm{~b}$ & 22.78 \\
\hline \multirow[t]{3}{*}{ Bion } & $4 \mathrm{mM}$ & $31.03 \mathrm{c}$ & 46.86 & $27.72 \mathrm{c}$ & 40.65 \\
\hline & $8 \mathrm{mM}$ & $28.90 \mathrm{c}$ & 50.50 & $25.83 \mathrm{c}$ & 44.70 \\
\hline & $1 \mathrm{mM}$ & $18.45 \mathrm{~d}$ & 68.40 & $16.94 d$ & 63.73 \\
\hline \multirow[t]{2}{*}{ Chitosan } & $2 \mathrm{mM}$ & $15.00 \mathrm{ef}$ & 74.31 & $14.55 \mathrm{e}$ & 68.85 \\
\hline & $3 \mathrm{mM}$ & $13.50 \mathrm{f}$ & 76.88 & $11.60 \mathrm{f}$ & 75.16 \\
\hline P. fluorescens & & $17.16 \mathrm{~d}$ & 70.60 & $15.01 \mathrm{~d}$ & 67.86 \\
\hline B. subtilis & & $19.09 \mathrm{de}$ & 67.31 & $17.00 \mathrm{e}$ & 63.61 \\
\hline Score fungicide & & $8.18 \mathrm{~g}$ & 85.98 & $6.79 \mathrm{~g}$ & 85.47 \\
\hline Control & & $58.38 \mathrm{a}$ & - & $46.71 \mathrm{a}$ & - \\
\hline
\end{tabular}

Data in Table (2) clearly revealed the ability of certain tested inducers to be near the fungicide efficiency (Score) in reducing the disease severity of CLS. In this regard, chitosan at $3 \mathrm{mM}$ was the nearest one to fungicide efficiency $(89.41 \%$ and 87.93$)$ in the two successive seasons 2018 and 2019, respectively followed by chitosan at $2 \mathrm{mM}$ which gave $86.43 \%$ and $80.55 \%$ and $P$. fluorescens ( 82.12 and $79.39 \%$ ), While bion at $2 \mathrm{Mm}$ gave the lowest efficiency for fungicide efficiency in reducing the disease severity of CLS $(35.79 \%$ and $26.65 \%)$ in the two successive seasons 2018 and 2019, respectively. 
Table 2: The percentage efficiency of different inducers treatments to fungicide efficacy on CLS under field conditions during two successive seasons 2018 and 2019.

\begin{tabular}{lccc}
\hline \multicolumn{1}{c}{ Treatments } & Conc. & Season 2018 & Season 2019 \\
\hline \multirow{3}{*}{ Bion } & $\mathbf{2} \mathbf{~ m M}$ & 35.79 & 26.65 \\
& $\mathbf{4} \mathbf{~ m M}$ & 54.50 & 47.56 \\
& $\mathbf{8 ~} \mathbf{~ M M}$ & 58.74 & 52.30 \\
\hline \multirow{3}{*}{ Chitosan } & $\mathbf{1 ~} \mathbf{~ M}$ & 79.55 & 74.56 \\
& $\mathbf{2} \mathbf{~ m M}$ & 86.43 & 80.55 \\
& $\mathbf{3} \mathbf{~ m M}$ & 89.41 & 87.93 \\
\hline P. fluorescens & & 82.12 & 79.39 \\
B. subtilis & & 78.28 & 74.42 \\
Score fungicide & & 100.00 & 100.00 \\
\hline
\end{tabular}

\subsection{Effect of inducers treatments on peanut pod yield:}

Regarding to peanut pod yield production, data in Table (3) illustrated that, peanut pod yield production significantly varied among the tested inducers and Score fungicide during two successive seasons 2018 and 2019. The highest peanut pod yield in two seasons produced with chitosan at $3 \mathrm{mM}$ followed by chitosan at $2 \mathrm{mM}$ and $B$. subtilis compared to other inducers treatments. While, the lowest pod yield produced by bion treatment at $2 \mathrm{mM}$ during the two growing seasons. On the other hand fungicide treatment recoded the highest value of peanut pod yield production.

Table 3: Impact of foliar spraying with inducers treatments on total peanut pod yield ( $\mathrm{Kg} / \mathrm{plot})$ under field conditions during two successive seasons 2018 and 2019.

\begin{tabular}{|c|c|c|c|c|c|}
\hline \multirow[b]{2}{*}{ Treatments } & \multirow[b]{2}{*}{ Conc. } & \multicolumn{2}{|c|}{ Season 2018} & \multicolumn{2}{|c|}{ Season 2019} \\
\hline & & $\begin{array}{c}\text { Yield } \\
\text { (Kg/plot) }\end{array}$ & $\begin{array}{c}* \text { Increases } \\
(\%)\end{array}$ & $\begin{array}{c}\text { Yield } \\
\text { (Kg/plot) }\end{array}$ & $\begin{array}{c}\text { *Increases } \\
(\%)\end{array}$ \\
\hline \multirow{3}{*}{ Bion } & $2 \mathrm{mM}$ & $2.44 \mathrm{~h}$ & 14.55 & $2.64 \mathrm{~g}$ & 14.78 \\
\hline & $4 \mathrm{mM}$ & $2.69 \mathrm{~g}$ & 26.29 & $3.05 \mathrm{e}$ & 32.61 \\
\hline & $8 \mathrm{mM}$ & $2.83 \mathrm{f}$ & 32.86 & $2.93 \mathrm{f}$ & 27.39 \\
\hline \multirow{3}{*}{ Chitosan } & $1 \mathrm{mM}$ & $3.19 \mathrm{~d}$ & 49.77 & $3.33 \mathrm{~d}$ & 44.78 \\
\hline & $2 \mathrm{mM}$ & $3.28 \mathrm{c}$ & 53.99 & $3.37 \mathrm{c}$ & 46.52 \\
\hline & $3 \mathrm{mM}$ & $3.37 \mathrm{~b}$ & 58.22 & $3.58 \mathrm{~b}$ & 55.65 \\
\hline P. fluorescens & & $3.15 \mathrm{e}$ & 47.89 & $3.33 \mathrm{~d}$ & 44.78 \\
\hline B. subtilis & & $3.21 \mathrm{~d}$ & 50.70 & $3.41 \mathrm{c}$ & 48.26 \\
\hline Score fungicide & & $3.57 \mathrm{a}$ & 67.61 & $3.74 \mathrm{a}$ & 62.61 \\
\hline Control & & $2.13 \mathrm{i}$ & 0.00 & $2.30 \mathrm{~h}$ & 0.00 \\
\hline
\end{tabular}

\subsection{Biochemical changes associated with induced resistance:}

The effect of certain inducers treatments, as foliar spraying, on various biochemical changes i.e. phenol content, activity of oxidative enzymes, total free amino acids and percentage of protein content in peanut leaves, was studied.

\subsubsection{Effect of inducers treatments on phenol contents:}

Results presented in Table (4) indicated that phenol contents including the free, conjugated and total phenols were obviously higher in plants treated with either inducers treatments than the untreated control during the two growing seasons 2018 and 2019.

In this respect peanut plant which induced by chitosan at $3 \mathrm{mM}$ and $P$. fluorescens followed by chitosan at $2 \mathrm{mM}$ recorded the highest phenol contents (total and free), while treated peanut plant with bion at $2 \mathrm{mM}$ gave the lowest phenol contents (total and free) compared to other treatments. Data also clearly indicated that, increasing the concentration of 
chemical inducer led to increase of phenols content (total and free). While, fungicide treatment recorded the lowest effect in the content of phenol in peanut leaves compared to other treatments during the two growing seasons 2018 and 2019 (Table 4).

Table 4: Effect of inducers treatments on phenol contents $(\mathrm{mg} / \mathrm{g}$ fresh weight) in peanut leaf plants.

\begin{tabular}{|c|c|c|c|c|c|c|c|}
\hline \multirow{3}{*}{ Treatments } & \multirow{3}{*}{ Conc. } & \multicolumn{6}{|c|}{ Phenol content } \\
\hline & & \multicolumn{3}{|c|}{ Season 2018} & \multicolumn{3}{|c|}{ Season 2019} \\
\hline & & Total & Free & Conjugate & Total & Free & Conjugate \\
\hline \multirow{3}{*}{ Bion } & $2 \mathrm{mM}$ & $8.544 \mathrm{f}$ & $6.679 \mathrm{ef}$ & $1.865 \mathrm{f}$ & $8.152 \mathrm{~g}$ & $4.932 \mathrm{f}$ & $3.220 \mathrm{~d}$ \\
\hline & $4 \mathrm{mM}$ & $9.619 \mathrm{~d}$ & $6.887 \mathrm{de}$ & $2.732 \mathrm{~b}$ & $8.641 \mathrm{e}$ & $5.097 \mathrm{e}$ & $3.544 \mathrm{c}$ \\
\hline & $8 \mathrm{mM}$ & $10.060 \mathrm{c}$ & $7.599 \mathrm{c}$ & $2.461 \mathrm{c}$ & $9.267 \mathrm{~d}$ & $5.449 \mathrm{~d}$ & $3.818 \mathrm{~b}$ \\
\hline \multirow{3}{*}{ Chitosan } & $1 \mathrm{mM}$ & $9.303 \mathrm{e}$ & $7.210 \mathrm{~d}$ & $2.093 \mathrm{e}$ & $6.158 \mathrm{j}$ & $4.674 \mathrm{~g}$ & $1.484 \mathrm{f}$ \\
\hline & $2 \mathrm{mM}$ & $10.165 \mathrm{c}$ & $8.347 \mathrm{~b}$ & $1.818 \mathrm{f}$ & $8.396 \mathrm{f}$ & $6.025 b$ & $2.371 \mathrm{e}$ \\
\hline & $3 \mathrm{mM}$ & $13.065 \mathrm{a}$ & $10.748 \mathrm{a}$ & $2.317 \mathrm{~d}$ & $11.215 \mathrm{a}$ & $8.881 \mathrm{a}$ & $2.334 \mathrm{e}$ \\
\hline P. fluorescens & & $12.466 \mathrm{~b}$ & $6.384 f$ & $6.082 \mathrm{a}$ & $11.014 \mathrm{~b}$ & $5.917 \mathrm{~b}$ & $5.097 \mathrm{a}$ \\
\hline B. subtilis & & $10.084 \mathrm{c}$ & $7.671 \mathrm{c}$ & $2.413 \mathrm{c}$ & $9.547 \mathrm{c}$ & $5.665 \mathrm{c}$ & $3.882 \mathrm{~b}$ \\
\hline Score fungicide & & $7.132 \mathrm{~h}$ & $5.514 \mathrm{~g}$ & $1.618 \mathrm{~g}$ & $7.750 \mathrm{~h}$ & $4.198 \mathrm{~h}$ & $3.552 \mathrm{c}$ \\
\hline Control & & $6.599 \mathrm{~g}$ & $4.147 \mathrm{~h}$ & $2.452 \mathrm{c}$ & $6.175 \mathrm{i}$ & $3.759 \mathrm{~g}$ & $2.416 \mathrm{e}$ \\
\hline
\end{tabular}

\subsubsection{Effect of inducers treatments on oxidative enzymes:}

Data in Table (5) showed that all tested inducers treatments increased the activity of oxidative enzymes i.e. peroxidase (PO), polyphenoloxidase (POP) and catalase (CAT) in peanut leaves compared to untreated control during the two growing seasons 2018 and 2019.

On this matter, the highest activity increase of PO showed when chitosan was used at 3 $\mathrm{mM}$ followed by P. fluorescens. The same trend was recorded in activity of PPO and CAT. Data showed also that, increase the concentration of chemical inducers was accompanied by increase of the activity of the tested enzymes. While, fungicide treatment recorded the lowest effect in the activity of oxidative enzymes compared to other treatments during the two successive seasons 2018 and 2019 (Table 5).

Table 5: Impact of inducers treatments on peroxidase (PO), polyphenoloxidase (PPO) and catalase activity in peanut leaf plants.

\begin{tabular}{lccccccc}
\hline \multirow{2}{*}{ Treatments } & \multirow{2}{*}{ Conc. } & \multicolumn{3}{c}{ Season 2018 } & \multicolumn{4}{c}{ Season 2019 } \\
\cline { 3 - 8 } & & $\mathbf{P O}$ & $\mathbf{C A T}$ & $\mathbf{~ P P O}$ & PO & CAT & PPO \\
\cline { 3 - 8 } Bion & $0.182 \mathrm{~h}$ & $0.038 \mathrm{~g}$ & $0.819 \mathrm{~h}$ & $0.197 \mathrm{i}$ & $0.038 \mathrm{e}$ & $1.202 \mathrm{~g}$ \\
& $\mathbf{4} \mathbf{~ m M}$ & $0.316 \mathrm{c}$ & $0.056 \mathrm{de}$ & $1.439 \mathrm{f}$ & $0.339 \mathrm{~h}$ & $0.084 \mathrm{c}$ & $2.470 \mathrm{e}$ \\
& $\mathbf{8} \mathbf{~ m M}$ & $0.502 \mathrm{~d}$ & $0.058 \mathrm{a}$ & $1.696 \mathrm{~d}$ & $0.634 \mathrm{c}$ & $0.118 \mathrm{~b}$ & $2.688 \mathrm{~d}$ \\
\hline \multirow{3}{*}{ Chitosan } & $\mathbf{1 ~} \mathbf{~ m M}$ & $0.254 \mathrm{~g}$ & $0.039 \mathrm{~g}$ & $0.928 \mathrm{~g}$ & $0.439 \mathrm{~g}$ & $0.048 \mathrm{~d}$ & $2.447 \mathrm{e}$ \\
& $\mathbf{2 ~} \mathbf{~ m M}$ & $0.437 \mathrm{e}$ & $0.047 \mathrm{f}$ & $1.630 \mathrm{e}$ & $0.595 \mathrm{~d}$ & $0.087 \mathrm{c}$ & $3.024 \mathrm{c}$ \\
& $\mathbf{3 ~} \mathbf{~ M M}$ & $1.029 \mathrm{a}$ & $0.127 \mathrm{~b}$ & $2.344 \mathrm{a}$ & $0.945 \mathrm{a}$ & $0.170 \mathrm{a}$ & $3.848 \mathrm{a}$ \\
\hline P. fluorescens & & $0.967 \mathrm{~b}$ & $0.069 \mathrm{c}$ & $1.997 \mathrm{~b}$ & $0.723 \mathrm{~b}$ & $0.119 \mathrm{~b}$ & $3.164 \mathrm{~b}$ \\
B. subtilis & & $0.830 \mathrm{c}$ & $0.059 \mathrm{~d}$ & $1.879 \mathrm{c}$ & $0.539 \mathrm{e}$ & $0.044 \mathrm{~d}$ & $2.670 \mathrm{~d}$ \\
Score fungicide & & $0.420 \mathrm{e}$ & $0.050 \mathrm{ef}$ & $1.604 \mathrm{e}$ & $0.527 \mathrm{f}$ & $0.040 \mathrm{e}$ & $1.934 \mathrm{f}$ \\
Control & & $0.177 \mathrm{~h}$ & $0.035 \mathrm{~g}$ & $0.724 \mathrm{i}$ & $0.191 \mathrm{i}$ & $0.026 \mathrm{f}$ & $1.062 \mathrm{~h}$ \\
\hline
\end{tabular}




\subsubsection{Effect of inducers treatments on total free amino acids and percentage of protein content:}

Results presented in Table (6) indicate that the inducers treatments caused obvious increase in total free amino acids comparing with the untreated control. Increase the concentration of chemical inducers lead to increasing of total free amino acids during the two growing seasons 2018 and 2019. Among all tested treatments, the highest total free amino acids content was produced by chitosan at $3 \mathrm{mM}$ followed by $P$. fluorescens, while bion at $2 \mathrm{mM}$ recorded the lowest amounts of total free amino acids compared to other inducers treatments in the two successive seasons.

Regard to the crude protein in peanut leaves was increased by all inducers treatments comparing with untreated control during the two successive seasons (Table 6). The rate of increase in crude protein was increased with increasing the chemical inducers concentration. On this matter, chitosan at $3 \mathrm{mM}$ followed by $P$. fluorescens produced the highest amount of crude protein while bion at $2 \mathrm{mM}$ recorded the lowest amounts during the two growing seasons. On the other hand, fungicide treatment recorded the lowest values of total free amino acids and crude protein in peanut leaves compared to other treatments during the two growing seasons 2018 and 2019 (Table 6).

Table 6: Impact of inducers treatments on total free amino acids and percentage of protein content in peanut leaf plants.

\begin{tabular}{|c|c|c|c|c|c|}
\hline \multirow[b]{2}{*}{ Treatments } & \multirow[b]{2}{*}{ Conc. } & \multicolumn{2}{|c|}{ Season 2018} & \multicolumn{2}{|c|}{ Season 2019} \\
\hline & & $\begin{array}{c}\text { Free amino acids } \\
\text { (mg/ g fresh } \\
\text { weight) }\end{array}$ & $\begin{array}{l}\text { Protein } \\
\text { content } \\
(\%)\end{array}$ & $\begin{array}{c}\text { Free amino acids } \\
\text { (mg/ g fresh } \\
\text { weight })\end{array}$ & $\begin{array}{c}\text { Protein } \\
\text { content } \\
(\%)\end{array}$ \\
\hline \multirow{3}{*}{ Bion } & $2 \mathrm{mM}$ & $0.560 \mathrm{f}$ & $7.81 \mathrm{gh}$ & $0.519 f$ & $7.16 \mathrm{~h}$ \\
\hline & $4 \mathrm{mM}$ & $0.567 f$ & $9.15 \mathrm{f}$ & $0.520 \mathrm{f}$ & $8.39 \mathrm{f}$ \\
\hline & $8 \mathrm{mM}$ & $0.712 \mathrm{~d}$ & $10.97 \mathrm{e}$ & $0.653 \mathrm{~d}$ & $10.06 \mathrm{e}$ \\
\hline \multirow{3}{*}{ Chitosan } & $1 \mathrm{mM}$ & $0.539 \mathrm{~g}$ & $8.05 \mathrm{~g}$ & $0.486 \mathrm{~g}$ & $7.38 \mathrm{~g}$ \\
\hline & $2 \mathrm{mM}$ & $0.681 \mathrm{e}$ & $13.17 \mathrm{~d}$ & $0.624 \mathrm{e}$ & $12.07 \mathrm{~d}$ \\
\hline & $3 \mathrm{mM}$ & $0.872 \mathrm{a}$ & $17.15 \mathrm{a}$ & $0.800 \mathrm{a}$ & $15.72 \mathrm{a}$ \\
\hline P. fluorescens & & $0.825 b$ & $16.11 \mathrm{~b}$ & $0.756 b$ & $14.77 \mathrm{~b}$ \\
\hline B. subtilis & & $0.769 \mathrm{c}$ & $14.71 \mathrm{c}$ & $0.704 \mathrm{c}$ & $13.49 \mathrm{c}$ \\
\hline Score fungicide & & $0.492 \mathrm{~h}$ & $7.40 \mathrm{~h}$ & $0.451 \mathrm{~h}$ & 7.11hi \\
\hline Control & & $0.381 \mathrm{i}$ & $6.64 \mathrm{i}$ & $0.350 \mathrm{i}$ & $7.00 \mathrm{i}$ \\
\hline
\end{tabular}

\section{Discussion}

Regarding to the effect of inducers treatments on diseases severity of peanut CLS, the results showed that, there was a significant effect of all treatments whether biotic or abiotic in reducing of studied disease and consequently increasing the total pod yield. Chitosan treatments at $3 \mathrm{mM}$ and $2 \mathrm{mM}$ followed by $P$. fluorescens were the most effective treatments during the two growing seasons 2018 and 2019. Increasing the concentration of the tested inducers caused an increasing in their reducing efficiency of diseases severity. In this respect, several reports have been published on use of chitosan as inducer treatment to control of plant diseases (Liu et al., 2007, Chakraborty et al., 2020 and De Vega et al., 2021). In this reports, the effect of chitosan in reducing disease incidence due to its effect in inhibited spore germination, germ tube elongation, and mycelial growth, where it acts as a catalyst to inhibit the growth of plant pathogens beside increase in the activities of polyphenoloxidase, peroxidase, enhanced the content of phenolic and synthesis of protein. More over treatments with chitosan result in induced resistance (IR) and enhanced resistance has been linked with priming of callose deposition and accumulation of the plant hormone jasmonic acid (JA), also Large-scale transcriptomic analysis revealed that chitosan primes gene expression at early time-points after infection (De Vega et al., 2021). This was confirmed in this study where chitosan treatment led to increase the activity of oxidative enzymes, total free amino acids and phenolic content as 
well as percentage of protein content. Moreover, this study proved the relationship between the increase of chitosan concentration and reduction of CLS.

In this study the effect of bion in induced resistance of CLS may be due to the increase of oxidative enzymes activity and content of phenol compounds. This is in agreement with Mahmoud et al., (2006) and Mahmoud et al., (2014), who stated that, effect of bion on reducing of reduced damping-off, root and pod rot incidence due to increase the activity of oxidative enzymes (catalase, peroxidase and polyphenoloxidase) and accumulation of phenol compounds in peanut plants. Besides that, in many plants investigated so far, Bion treatment is associated with increases in activities of many classes of pathogenesis-related protein (Gorlach et al., 1996, Abou-Taleb, 2001 and Mosa 2002).

The study also demonstrated the ability of Bacillus subtilis and Pseudomonas fluorescens to induce resistance in peanut plants against CLS and this is matching with Van et al., (1998), Verhagen et al., (2010), Gruau et al., (2015) and Jayapala et al., (2019) who stated that, Plant growth-promoting rhizobacteria (PGPR) can induce a systemic resistance in plants that is phenotypically similar to pathogen-induced systemic acquired resistance (SAR). Rhizobacteria also induced systemic resistance (ISR) has been demonstrated against fungi, bacteria, and viruses also, many strains of plant growth-promoting rhizobacteria were reported to induce systemic resistance against a broad spectrum of soil-borne and foliar pathogens (Altinok et al., 2013). PGPR induced systemic resistance by triggering jasmonic acid (JA), ethylene synthesis and pathogenesis related (PR) proteins (Altinok et al., 2013). Moreover, Pseudomonas fluorescens can reduce disease in plant tissues through induction of resistance by triggered an oxidative burst and production phytoalexin (i.e. resveratrol and viniferin) and enhanced the oxidative enzymes activity (Verhagen et al., 2010 and Gruau et al., 2015) and this is in agreement with the results of this study.

The present investigation indicated that, there is a correlation between induced resistance and some biochemical changes in plant tissues like increase in the activity of oxidative enzymes, accumulation of phenols compounds, total amino acid and percentage of crude protein. This biochemical changes became a marker to induce resistance (Reuveni et al., 1992), that due to the role of oxidative enzymes activity in disease development that has been correlated with the expression of resistance in different host - pathogen system such as, lignin production, phenol accumulation, linking of pre-existing hydroxyproline-rich structural proteins in the cell wall, making the cell wall more resistant to degradation by microbial enzymes and generated hydrogen peroxide which, consider an antimicrobial agent (Cadena-Gomez and Nicholson, 1987, Apostol et al., 1989, Edreva, 1989, Peng and Kuc, 1992 and Mamoud et al., 2014). While, phenol compounds play an important role in plant defense such, phenols are essential for the biosynthesis of lignin, which consider an important structural component of plant cell walls (Hahlbrock and Scheel, 1989). Phenol compounds in peanut seeds have been conducted concerning the effects of elicitors, such as chitosan. (Ebel and Hahlbrock, 1982).

The obtained data clearly showed the ability of certain inducers treatments to have similar efficacy near to the fungicide efficiency (Score) in reducing CLS disease of peanut this may lead to the conclusion that application of inducers is applicable, safe and cost effective method for controlling peanut CLS. Also, the use of inducers in agriculture could be a suitable alternative for integration in disease control systems and could act sometimes as main or adjuvant antimicrobial compounds and do not leave a toxic residue in the product.

\section{Reference}

A.O.A.C., 1998. Official Method of Analysis of Official Analytical Chemists $16^{\text {th }}$ ed. Kenneth Helrich edit. Published by the Association of Official Analytical Chemists Inc, Virginia, USA.

Abdel Aal - Ahlam E., Dawlat A. Abd-El-Kader,M.A. Khedr and M. M. A Khalifa, 2012. Induction of resistance in sesame plants against charcoal rot diseases by some chemical inducers. Zagazig J. Agric. Res., 39 (2): 189-202. 
Abou-Taleb, M.A., 2001. Biochemical changes associated with the application of some resistance-inducing compounds for controlling powdery mildew of cucumber. Egypt. J. Appl. Sci. 16: 387-405.

Allam, A. I. and S. P. Hollis, 1972. Sulfide inhibition of oxidase in rice root. Phytopathology, 62: 634-639.

Altinok H. H., M. Dikilitas and H. N. Yildiz, 2013. Potential of Pseudomonas and Bacillus isolates as biocontrol agents against Fusarium wilt of eggplant. Biotechnol. \& Biotechnol. Eq. 27 (4): 3952-3958.

Apostol, I.; P.P. Heinstein and P.S. Low, 1989. Rapid stimulation of an oxidative burst during elicitation of cultured plant cells. Plant Physiol., 90: 109-116.

Cadena-Gomez, G. and R. L. Nicholson, 1987. Papilla formation and associated peroxidase activity: A non-specific response to attempted fungal penetration of maize. Physiol. Mol. Plant Pathol., 31: 51-67.

Chakraborty M., M. Hasanuzzaman, M. Rahman, A.R. Khan, P. Bhowmik, N.U. Mahmud, M. Tanveer and T. Islam, 2020. Mechanism of Plant Growth Promotion and Disease Suppression by Chitosan Biopolymer. J. Agric., 10, (624):1-30.

CoStat, 2005. CoStat program, version 6.4. CoHort software, Monterey, CA, USA.

De Vega D., N. Holden, E. P .Hedley., J. Morris1, E .Luna and A. Newton (2021). Chitosan primes plant defense mechanisms against Botrytis cinerea, including expression of Avr9/Cf-9 rapidly elicited genes. Plant Cell Environ., 44:290-303.

Dwivedi, S.L., J.H. Crouch, S.N. Nigam, M.E. Ferguson and A.H. Paterson, 2003. Molecular breeding of groundnut for enhanced productivity and food security in the semiarid tropics: Opportunities and challenges. Advanced Agronomy, 80:153-221.

Ebel, J; and K. Hahlbrock, 1982. Biosynthesis pp 641-679, In: The Flavonoids: Advances in Research. (J. B. Harbome and T. J. Mabry), eds. Chapman and Hall, London.

Edreva, A., 1989. Host-parasite relations: Biochemistry. Pages 105-140 in: Blue Mold of Tobacco. W. E. Mckeen, ed. The American Phytopathological Society, St. Paul, MN.

FAO., 2011. FAOSTAT. Available at http://faostat.fao.org/default.aspx (verified 6 June 2011) FAO, Rome, Italy.

Garcia, J.E., 1993. Pesticides as contaminants. Turrialba (Costa Rica), 43(3) 221-229 (c.f. Rev. Pl. Pathol., 74(6): 409, 1995).

Goldschmidt, E.E., R. Goren and S.P. Monselise, 1968. The IAA oxidase system of citrus roots. Planta, 72: 213-222.

Gorlach, J., S. Volorath, G. Knaut-Beiter, G. Hengy, U. Beckhove, K.H. Kogel, M. Ostendrop, T. Staub, E. Ward, H. Kessmann and J. Ryals, 1996. Benzothiadiazol a novel class of inducers of systematic acquired resistance activate gene expression and disease resistance in wheat. Plant Cell, 8: 629-643.

Gruau C., P. Trotel, A.S. Villaume, F. Rabenoelina, C. Clément, F. Baillieul and A. Aziz, 2015. Pseudomonas fluorescens PTA-CT2 Triggers Local and Systemic Immune Response against Botrytis cinerea in Grapevine. Mol Plant Microbe Interact., 28(10): 17-29.

Hahlbrock, K. and D. Scheel, 1989. Physiology and molecular biology of phenylpropanoid metabolism. Annu. Rev. Plant Physiol. Plant Mol. Biol., 40: 347-369.

Hussien-Zeinab N.E., 2011. New approaches for controlling peanut root and pod rots diseases caused by Rhizoctonia solani. Ph.D. Thesis, Inst. of African Res. and Studies, Cairo Univ, $138 \mathrm{pp}$.

Izge, A.U., Z.H. Mohammed and A. Goni, 2007. Levels of variability in groundnut (Arachis hypogaea L.) to Cercospora leaf spot disease-implication for selection. African Journal of Agricultural Research, 2(4):182-186.

Jayapala N., H.N. Mallikarjunaiah, H. Puttaswamy, H. Gavirangappa, and N.S. Ramachandrappa, 2019. Rhizobacteria. Bacillus spp. Induce resistance against anthracnose disease in chili (Capsicum annuum L.) through activating host defense response Jayapala et al. Egyptian Journal of Biological Pest Control, 29:45pp1-9.

Karunanithi, K., M. Muthusamy and K. Seetharaman, 2000. Pyrolnitrin production by Pseudomonas fluorescens effective against Macrophomina phaseolina. Crop Res. (Hisar), 19: 368-370 (C.F. CAB Abstracts 2000). 
Kuc, J., 1982. The immunization of cucurbitsm against fungal, bacterial and viral disease. pp. 137-155 In: Plant Infection. The Physiological and Biochemical Basis, (Y. Asada, W.R. Buohnell S. Ouchi and C.P. Vance) Ed. Japanese Science Society Press, Tokyo.

Lijun Wu, J.P. Damicone, J.A. Duthie and H.A. Melouk, 1999. Effects of temperature and wetness duration on infection of peanut cultivars by Cercospora arachidicola. Phytopathology, 89: 653-659.

Littrell, R.H., 1974. Tolerance in Cercospora arachidicola to benomyl and related fungicides. Phytopathology 64:1377-1378.

Liu J.S., T. Xianghong and M.Y. Xu, 2007. Effects of chitosan on control of postharvest diseases and physiological responses of tomato fruit. Postharvest Biology and Technology 44: 300-306.

Mahmoud, E.Y., Samia Y.M. Shokry and Zeinab N. Hussin, 2006. Induction of resistance in peanut plants against root rot diseases under greenhouse conditions by some chemical inducers. J. Agric. Sci. .Mansoura Univ., 31(6):3511-3524.

Mahmoud, E.Y., M. M. Ibrahim., Wagida A. M. Saleh and M.I.M. Ahmed, 2016. Compatibility between antagonistic fungi and bacteria and their influence in controlling sunflower charcoal rot. $13^{\text {th }}$ Cong. Phytopathol 10-11 may Giza, Egypt (Abstract).

Mahmoud, E.Y., Wagida A.M. Saleh and Zeinab N. Hussien, 2014. Biochemical change associated with induced resistance to peanut root and pod rots diseases_ Minufiya J. Agric. Res. Vol.39 No. 4(1): 1227-1253.

Mandal, S., N. Mallicka and A. Mitraa, 2009. Salicylic acid-induced resistance to Fusarium oxysporum f. sp. lycopersici in tomato. Plant Physiology and Biochemistry, 47(7): 642649.

Maninderpal, S., 2011. Physiological consequence of late leaf spot on peanut Arachis hypogaea L.) cultivars of differing resistance. Ph.D. Thesis, Florida Univ., 138.

Matta, A. and A.E. Dimond, 1963. Symptoms of Fusarium wilt in relation to quantity of fungus and enzyme activity in tomato stems. Phytopathology, 53: 547-587.

Maxwell, D.P. and D.F. Bateman, 1967. Changes in the activities of some oxidases in extracts of Rhizoctonia infected bean hypocotyle in relation to lesion maturation. Phytopathology, 57: 132-136.

Meena, B.; T. Marimuthu and R. Velazhahan, 2001. Salicylic acid induces systemic resistance in groundnut against late leaf spot caused by Cercosporidium personatum. J. Mycology Plant Path., 31: 139-145. (C.F. CAB Abstracts 2003).

Moore, S. and W. H. Stein, 1954. A modified ninhydrin reagent for photometric determination of amino acids and related compounds. J. Biol. Chem., 211: 907-913.

Mosa, A.A., 2002. Induced resistance in rice against blast disease using abiotic and biotic agents. Annales Agric. Sci., Ain Shams Univ., Cairo, Egypt, 47: 993-1008.

Peng, M. and J. Kuc, 1992. Peroxidase-generated hydrogen peroxide as a source of antifungal activity in vitro and on tobacco leaf discs. Phytopathology, 82: 696-699.

Reuveni, R., M. Shimoni, Z. Karchi and J. Kuc, 1992. Peroxidase activity as a biochemical marker for resistance of muskmelon (Cucumis melo) to Pseudoperonospora cubensis. Phytopathology, 82:749-753.

Shokes, F.M. and A.K. Culbreath, 1997. Early and late leaf spots. p. 17-20. In N. KokalisBurelle, D.M. Porter, R. Rodriguez-Kabana, D.H. Smith, and P. subrahmanyam (eds.) Compendium of Peanut Diseases, 2nd Ed. APS Press St. Paul, MN.

Snell, F.D. and C.I. Snell, 1953. Colorimetric Methods. Vol. III. D. Van No strand Co. Inc., Torento, N. Y., London, $606 \mathrm{pp}$.

Subrahmanyam P., D. McDonald, F.L. Walliyar, J. Raddy, S.N. Nigam, R.W. Gibbons, R.V Rammanatha, A.K Singh, S. Pande, P.M Reddy and P.V Subba Rao, 1995. Screening methods and sources of resistance to rust and late leaf spot of groundnut. Bull. 47. ICRISAT, Patencheru, India, $20 \mathrm{pp}$.

Tuzun, S. and J.W. Kloepper, 1994. Induced systematic resistance by plant growth promoting rhizobacteria. In M.H. Ryder, P.M. Stephens and G.W. Bowen (eds), Improving Plant Productivity with Rhizosphere Bacteria, Proc. $3^{\text {rd }}$ International Workshop on Plant 
Growth Promoting Rhizobacteria, CSRIO, Australia, pp. 104-109 (C.F. CAB Abstracts 2000).

Van, L.C., P.A. Loon, H.M. Bakker and I.C. Pieterse, 1998. Systematic resistance induced by rhizosphere bacteria. Annual Review of Phytopathology 36:453-483.

Verhagen B.W.M., P.A. Trotel, M. Couderchet, M. Höfte and A. Aziz, 2010. Pseudomonas spp.-induced systemic resistance to Botrytis cinerea is associated with induction and priming of defense responses in grapevine. Affiliations expand. J Exp Bot., 61(1):249-60.

Walters, D., A. Newton and G. Lyon, 2007. Induced Resistance for Plant Defense. Blackwell Publishing Editorial Offices, $269 \mathrm{pp}$.

Woodward, J.E., T.B. Brenneman, R.C. Kemerait Jr, A.K. Culbreath and N.B. Smith, 2010. Management of peanut diseases with reduced input fungicide programs in fields with varying levels of disease risk. Crop Prot., 29:222-229. 